\title{
Information Entropy in Translation: Psycholinguistic Aspects
}

\section{Інформаційна ентропія у перекладі: психолінгвістичні аспекти}

\section{Marharyta Dorofeieva ${ }^{1}$}

Dr. in Philology,

Assistant Professor
Маргарита Дорофесва ${ }^{1}$

доктор філологічних наук, доцент

E-mail: margarita dorofeeva@hotmail.com orcid.org/0000-0003-2024-4806

Tatiana Andrushchenko ${ }^{2}$

Dr. in Philosophy, Head of

the Social Science Department
Тетяна Андрущенко 2

доктор філософських наук, завідувач кафедри суспільних наук

E-mail: gerasimenko.tanya@gmail.com orcid.org/0000-0002-0381-171X

${ }^{1}$ Kyiv National Taras Shevchenko University, Institute of Philology,

Department of German Philology and Translation

14, Taras Shevchenko Blvd., Kyiv, Ukraine, 01601

${ }^{2}$ Ukrainian National Tchaikovsky Academy of Music

1-3/11, Architect Gorodetsky Str., Kyiv, Ukraine, 01011
${ }^{1}$ Київський національний університет імені Тараса Шевченка, Інститут філології, кафедра германської філології та перекладу бульвар Тараса Шевченка, 14, Київ, Україна, 01601

${ }^{2}$ Наиіональна музична академія України імені П.І. Чайковського

$\triangle$ вул. Архітектора Городецького, 1-3/11, Київ, Україна, 01011

Original manuscript received October 21, 2018

Revised manuscript accepted August 13, 2019 


\section{ABSTRACT}

The article deals with the category of informational entropy in the source text as a matter of translation psycholinguistics. The informational entropy of the lexical units on different levels in the source text refers to subjective factors that reduce the translation quality. Lexical units-carriers of the source text's informational entropy cause informational deficits in the translator's consciousness.

The aim of the search is to consider the category of informational entropy from the standpoint of psycholinguistics and cognitive translation theory, identify the causes of informational entropy, establish linguistic and genre-stylistic markers of the lexical entropy units in the source text, identify ways to minimize entropy in the specialized translation.

The research procedure involves a psycholinguistic experiment with the participation of 85 informants with semi-professional translation status. The participants produced a German-Ukrainian translation of a specialized text, in which the number of lexical units contained informational entropy as a percentage of the total words' number was $17.9 \%$.

The results of the translation's comparative analysis indicate similar psycholinguistic mechanisms for understanding lexical units with informational entropy, leading to false translation solutions in the target texts. Such mechanisms include an incorrect choice of the translation method and a lack of attention to the extralinguistic information in the source text.

The conclusions of the psycholinguistic experiment confirm the universal nature of the informational entropy, resulting in translation quality degradation. The psycholinguistic factor for the false translation solutions is an automatic suppression the contextual meaning of the source text's lexical item by its subject-logical meaning in the translator's mind, realized in the incorrect choice of the translation method.

Key words: informational entropy, lexical level, source text, target text, psycholinguistic experiment, sign-oriented translation method, sense-oriented translation method, translator's competence.

\section{Вступ}

Сучасна антропоцентрична теорія перекладу демонструє спільні ознаки 3 іншими дисциплінами поля гуманітарних наук, насамперед міжпредметні зв’язки з психолінгвістикою. Дослідження процесуальних аспектів та діяльнісне розуміння перекладу утворюють площину перетину перекладознавства і психолінгвістики як дотичної галузі мовознавства.

Якщо взяти за основу визначення предмета й об’єкта психолінгвістики, можна встановити однозначні паралелі та 
споріднені категорійно-понятійні відношення між психолінгвістикою та, зокрема, когнітивною транслятологією. Так, О. Селіванова формулює предмет психолінгвістики як співвідношення психічних функцій і процесів свідомості з мовною здатністю й мовленнєвою діяльністю людини. Об'єкт психолінгвістики, на думку дослідниці, охоплює мовну здатність і мовленнєву діяльність особистості (Селіванова, 2008).

У той же час об'єкт теорії перекладу становить особливий вид мовленнєвої діяльності, цілеспрямовану діяльність, що відповідає певним вимогам та орієнтується на досягнення конкретного результату (Швейцер, 1988). Синтез психолінгвістики й теорії перекладу здатний забезпечити погляд у приховані перекладацькі процедури сприйняття, розуміння, інтерпретації оригіналу та продукування цільового тексту.

За останні роки психолінгвістичні аспекти перекладацької діяльності привертають все більше уваги вітчизняних дослідників у галузях методики й дидактики спеціального перекладу (Chernovaty \& Kovalchuk, 2019), формування професійної компетенції перекладача, у тому числі в усному двосторонньому перекладі (Bogush, Korolova \& Popova, 2019). Зарубіжні розвідки психолінгвістичного напряму в перекладознавстві висвітлюють, зокрема, взаємозв'язок між типом перекладацьких помилок і когнітивними процесами у мозку перекладачів-білінгвів (Hatzidaki \& Pothos, 2008), питання невизначеності перекладу в контексті та поза контекстом (Prior, Wintner, MacWhinney \& Lavie, 2011), закономірності реалізації когнітивних стратегій розуміння, прийняття рішень та ревербалізації з боку перекладача (House, 2013), залежність між довжиною слова та його концептуальною складністю для перекладу (Lewis \& Frank, 2016), аспекти когнітивної ергономіки у перекладацькому процесі (Teixeira \& O’Brien, 2017).

Оскільки процес перекладу, а саме та його ментальна частина, що не піддається безпосередньому спостереженню, має психологічну природу, нагальними питаннями перекладознавства в аспекті психолінгвістики залишаються: (а) створення методології когнітивно-трансляційних досліджень 3 погляду психолінгвістики; (б) напрацювання когнітивних моделей перекладу-якпроцесу; (c) алгоритмізація методик вивчення когнітивних процедур трансляції. 
Інформаційна ентропія у перекладі: психолінгвістичні аспекти

Когнітивно-діяльнісні положення перекладознавства, насамперед поняття самоорганізації та інформащіï, суголосні 3 психолінгвістичним розумінням мовленнєвої організації як одного 3 механізмів мовленнєвої діяльності людини. Так, О. Залевська наділяє мовленнєву організацію усіма ознаками самоорганізованої системи: «(1) мовленнєва організація людини $\epsilon$ не пасивною скарбницею знань про мову, а динамічною функціональною системою; (2) підкреслюється постійна взаємодія між процесом переробки й упорядкування мовленнєвого досвіду та іiі продуктом <..>; (3) названі положення створюють базу для трактування мовленнєвої організації людини як самоорганізованої системи» (Залевская, 2000: 30).

Суб'єкт перекладу як активний учасник глобальної системи самоорганізації перекладацької діяльності у всій сукупності об'єктивних відношень між текстом оригіналу, комунікативною ситуацією, фаховим дискурсом, ноосферою, культурою та цільовим текстом має свою локальну суб'єктивну систему самоорганізації, зумовлену психофізіологічною мовленнєвою організацією індивіда. Вплив суб'єктивної системи самоорганізації перекладача на перекладацькі рішення як «відбиток» несвідомих процесів обробки інформації у тексті перекладу становить, на нашу думку, предмет вивчення психолінгвістики перекладу.

Прикладом кооперативного зв'язку між елементами внутрішнього рівня будь-якої самоорганізованої системи та зовнішнім середовищем слугує перенесення енергії, речовини та інформаціï (Haken et al., 2016). У свою чергу, поняття інформації, ключове для психолінгвістики і перекладознавства, протистоїть поняттю інформаційної ентропії.

Явище інформаційної ентропії у перекладі в ракурсі психолінгвістики за винятком окремого розділу монографії T. Андрієнко (2016) залишається мало дослідженою темою у вітчизняній науці. Серед розвідок зарубіжних дослідників, що розглядали феномен ентропії в галузі психолінгвістики і в дотичних сферах обробки природної мови, корпусної лінгвістики і комерційної лексикографії, слід згадати, зокрема, Р. Байєна (Baayen, 2005) та Ф. Келлера (Keller, 2004), який займався визначенням коефіцієнту ентропії на синтаксичному рівні, зокрема, кореляцією між ентропією речення, його довжиною та позицією всередині тексту. 
Недостатня розробленість проблем психолінгвістики перекладу, пов'язаних із ментальними процедурами обробки інформації та суб'єктивними факторами впливу на вибір перекладацького рішення, серед яких чільне місце займають інформаційні дефіцити перекладача (інформаційна ентропія), зумовлює актуальність розвідки.

Об'єктом дослідження виступають лексичні одиниці-носії інформаційної ентропії (IE) тексту оригіналу.

Предмет розвідки складають психолінгвістичні особливості відтворення лексем-носіїв IE оригіналу в перекладі.

Мета статті полягає у висвітленні категорії інформаційної ентропії як психолінгвістичного фактору зниження якості перекладу, і встановленні стратегій подолання IE у перекладі спеціальних текстів.

Заявлена мета передбачає вирішення таких конкретних завдань: 1) дати визначення психолінгвістичного феномена IE; 2) виявити психолінгвістичні причини виникнення інформаційної ентропії; 3) встановити мовні та жанрово-стилістичні ознаки IE лексичних одиниць; 4) скласти інвентар типових лексичних одиниць-носіїв IE; 5) встановити характер впливу одиниць-носіїв IE на перекладацькі рішення в психолінгвістичному аспекті; 6) запропонувати шляхи мінімізації суб'єктивної IE вихідного тексту (ВТ) у спеціальному перекладі. Розглянемо експериментальну частину розвідки.

\section{Методи та методики дослідження}

Для розв'язання поставлених наукових завдань автором статті було проведено психолінгвістичний експеримент серед студентівмагістрів Інституту філології Київського національного університету імені Тараса Шевченка. В експерименті взяли участь студенти першого та другого курсу магістратури спеціальності «Філологія», що навчались за освітньо-науковими програмами «Галузевий переклад 3 німецької та англійської мови; міжкультурний менеджмент» i «Германістика. Міжкультурний менеджмент та переклад (німецька, англійська мови)».

Матеріалом розвідки слугували: 1) контрольний фрагмент офіційно-ділового тексту жанру «протокол» німецькою мовою; 
2) офіційний переклад фрагмента українською мовою в авторстві штатного перекладача організації Гете-Інститут в Україні (м. Київ); 3) множинні українські трансляти, виконані напівпрофесійними перекладачами - учасниками експерименту. 3 метою експертної оцінки й моніторингу результатів дослідження були використані фрагменти авторського перекладу.

Експеримент проводився протягом 2017-2018 навчальних років під час зимової семестрової атестації. Умови експерименту включали виконання контрольного завдання в рамках модульної контрольної роботи (МКР) 3 дисципліни «Жанрові теорії перекладу». Загальна кількість учасників склала 85 осіб, 3 них 43 особи на той час перебували на першому курсі магістратури обох спеціальностей, а 42 інформанти навчались на другому курсі магістерських програм. Кожна група отримала завдання, що передбачало німецько-український переклад фрагмента спеціального тексту з використанням наданої екстралінгвістичної інформації.

Відповідно до умов експерименту було обрано текст 3 максимально високою абсолютною частотою уживання одиницьносіїв інформаційної ентропії 3 метою перевірки їхнього відтворення у трансляті. Відсоткове відношення кількості одиниць IE до загальної кількості слів у тексті фрагмента склало 17,97\%, що в абсолютній кількості дорівнює 16 повнозначним одиницям інформаційної ентропії на 89 слів тексту загалом без урахування повторів.

На етапі обговорення, який проходив під час останнього (залікового) заняття, множинні переклади групи порівнювались 3 офіційним перекладом та перекладом керівника експерименту. Учасники експерименту коментували власні трансляти у вигляді ТАР-протоколу перекладацьких рішень. Заключний моніторинг i оцінка результатів перекладу проводились керівником разом 3 інформантами. Наведемо приклад авторського завдання МКР для групи інформантів (табл. 1).

У таблиці 1 представлені структурні та змістові елементи контрольного завдання групи: (1) формулювання завдання (інструкція) німецькою мовою; (1.1) екстралінгвістична інформація для перекладача, що формує найближчий ситуативний контекст i полегшує розуміння комунікативної ситуації оригіналу; (1.2) безпосередній фрагмент ВТ, призначений для перекладу. 
Таблиця 1. Структура й зміст контрольного завдання

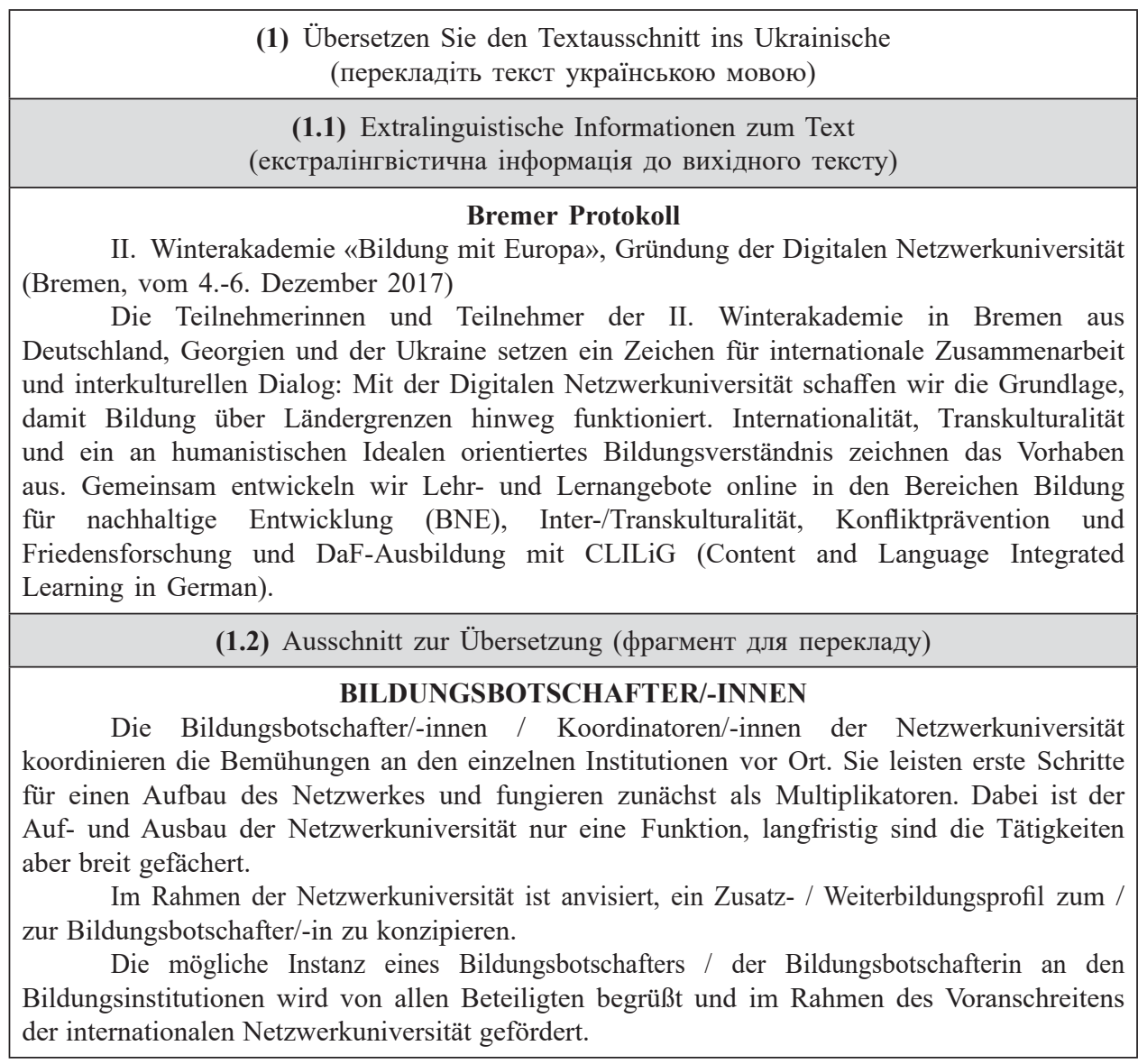

Окремо зазначимо, що незважаючи на контрольовані умови проведення експерименту (обмежений час i місце виконання завдань), учасникам було дозволено користуватись перекладацькими артефактами - електронними та паперовими словниками, а також інформацією 3 мережі Інтернет. Такі правила мали на меті максимально наблизити інформантів до реальної ситуації виконання перекладу.

\section{Результати та дискусії}

Розглядаючи ентропію як психолінгвістичний фактор помилкових перекладацьких рішень, необхідно в першу чергу 
надати визначення цьому поняттю в контексті психолінгвістики і когнітивної теорії перекладу.

У межах дисертаційного дослідження, присвяченого синергетиці перекладу, ми запропонували таку дефініцію: ентропія інформаційна $y$ перекладi - міра невизначеності інформації про об’єкт перекладу (інформаційний дефіцит перекладача), який зумовлює хибні перекладацькі рішення на будь-якому рівні системи самоорганізації спеціального перекладу (Дорофеєва, 2017). Згадана невизначеність може існувати як (а) на об'єктивному рівні одиниць перекладу вихідного тексту (мовні ознаки одиниць перекладу), (b) на об'єктивному рівні комунікативної ситуації (відсутність даних про фактори комунікативної ситуації, до якої входить ВТ), (с) на об’єктивному рівні дискурсу (значні розбіжності між нормами вихідного та цільового спеціальних дискурсів), так i на суб’єктивному рівні виконавця перекладу (недостатня мовна, перекладацька, дискурсивно-фахова, пошукова компетенція). Саме суб'єктивні фактори виникнення IE цілого тексту та його окремих одиниць в голові перекладача становлять психолінгвістичний аспект когнітивної теорії перекладу.

Одразу слід зауважити, що процеси міжмовного та міжкультурного перетворення, які відбуваються у нейронних мережах мозку перекладача (так званий Black Box), на сьогоднішній день піддаються реконструкції лише «на виході», за допомогою аналізу перекладацьких рішень готового трансляту (Prunč, 2012). Традиційними інструментами такого аналізу слугують ТАР-протоколи та спеціальні алгоритми порівняльноперекладацьких досліджень ВТ і ЦТ на базі когнітивних моделей процесу перекладу.

Іншим важливим питанням 3 погляду визначення факторів IE, релевантних для психолінгвістики, стає створення когнітивної типології перекладацьких помилок, де хибні перекладацькі рішення розмежовуються за типами інформації, що відповідають рівням глобальної системи самоорганізації перекладацького процесу: рівень цільової мови (структурно-семантична інформація) - рівень спеціального цільового дискурсу (комунікативно-прагматична i дискурсивно-фахова інформація) - рівень ноосфери (фонова/ енциклопедична інформація). Явище інформаційної ентропії, таким чином, утворює проміжну ланку між глобальною та локальною 
системою самоорганізації перекладацької діяльності, яка знаходиться в мозку перекладача. Перейдімо до питання причин виникнення IE та характеру конкретних одиниць-носіїв інформаційної невизначеності вихідного тексту як об'єкта перекладу. 3 позицій когнітивної транслятології спостерігається зворотна закономірність: чим вище дефіцит інформації (IE) для перекладача у вихідному тексті загалом, тим нижче якість перекладу, аж до повного нерозуміння вихідного тексту та відмови суб'єкта перекладу від виконання замовлення. Навпаки, якщо ентропія ВТ для перекладача дорівнює нулю (немає інформаційних дефіцитів на рівні мови, комунікативної ситуації, дискурсу i ноосфери), тоді не виникає складнощів у процесі перекладу.

Це означає, що для виконавця з високим рівнем перекладацької компетенції у широкому значенні рівень IE вихідного тексту завжди нижчий, ніж для непрофесійного або напівпрофесійного перекладача. Цей факт пояснює широку практику пріоритетного надання перекладацьких замовлень виконавцям 3 перекладацькою освітою, але без достатніх фахових знань, порівняно 3 фахівцями без перекладацької підготовки, але зі знанням іноземної мови. Тому до суб'єктивних факторів IE відносимо наявність та ступінь розвиненості компетенцій перекладача.

За попередньою гіпотезою, IE виникає на рівні тексту (текст зрозумілий або незрозумілий для виконавця). Втім, незрозумілий текст 3 високим рівнем IE становить не причину, а наслідок інформаційного дефіциту перекладача. Тому логічно припустити, що ентропія може бути притаманна усім повнозначним та структурно-композиційним одиницям перекладу ВТ: лексемам, словосполученням, колокаціям, стійким виразам, реченню, надфразовій єдності. Серед об'єктивних ознак мовних одиницьносіїв IE Т. Андрієнко (2014) називає: 1) непередбачуване уживання одиниці з огляду на тип вихідного тексту, контексту, стиль, дискурс та культуру; 2) одиниці, які припускають інші варіанти вираження одного й того самого смислу. 3 нашого боку зауважимо, що носіями IE можуть ставати також одиниці, які мають один варіант вираження різних смислів у різних дискурсах/терміносистемах (наприклад, полісеманти, міжсистемні термінологічні омоніми). Отже, мовним критерієм високого рівня IE одиниць перекладу стають синонімія i 
багатозначність, а до жанрово-стилістичних критеріїв IE належить непередбачуваність уживання.

Відповідно до обраного об'єкта дослідження зосередимось на одиницях-носіях IE лексичного рівня мови. На нашу думку, інформаційна ентропія лексичного рівня пов'язана 3 подвійною реалізацією контекстуального та предметно-логічного значення лексичної одиниці у свідомості перекладача. Причому під час сприйняття ВТ обидва значення вступають між собою в конкурентні відношення, а під час інтерпретації та продукування цільового тексту одне значення 3 двох «перемагає», витісняючи інше значення у свідомості суб'єкта перекладу. В процесі локальної самоорганізації підсвідомо обирається спосіб перекладу конкретної одиниці: знаковий або смисловий. Результатом «конкурентної боротьби» обох значень стає відтворення одиниці перекладу за обраним способом.

Власний перекладацький і дидактичний досвід автора в галузі німецько-українського перекладу, що становить більше 20 років, дозволяє визначити перелік типових одиниць-носіїв IE оригіналу.

До таких одиниць належать переважно: 1) абстрактні віддієслівні іменники (Aufbau, Ausbau, Rechtfertigung, Vermögensabschöpfung, Geltung, Thematisierung, Setzung, Zuständigkeitsverteilung, Äußerung, Voraussetzung, Voranschreiten); 2) абстрактні складні іменники 3 двома або більше основами (Bildungsbotschafter, Zusatzprofil, Geltungsanspruch, Haushaltskreislauf, Orientierungshilfe, Rechtsrahmen, Gesichtspunkt, Gegenstand, Bewusstsein); 3) абстрактні однокореневі іменники (Instanz); 4) абстрактні дієслова (angleichen, weiterleiten, erstatten, fördern); 5) ментальні дієслова (aufgreifen, konzipieren, anschneiden, wahrnehmen); 6) стереотипні формули та кліше (in den Genuss kommen, erste Schritte leisten, den Unterschied machen); 7) складні прикметники, прислівники, дієприслівники у функції означення й обставини (gegliedert, gefächert, netztauglich, langfristig, ersichtlich).

Якщо ми проаналізуємо наведений список в ізольованому вигляді, можна побачити, що практично всі наявні в ньому лексеми задовольняють критеріям полісемії та/або синонімії, тобто стають потенційними носіями IE. Інший критерій IE цих одиниць - непередбачуване уживання - можна встановити лише в конкретному тексті. 
Розгляньмо одиниці-носії IE лексичного рівня фрагмента вихідного тексту (Bremer Protokoll, 2017), запропонованого учасникам експерименту, та їхнє відтворення в офіційному перекладі.

Насамперед необхідно окреслити комунікативну ситуацію, до якої входить ВТ, встановити пріоритетну функцію та жанрову належність оригіналу. Вихідний текст має назву «Bremer Protokoll. II. Winterakademie - Bildung mit Europa» (укр. Бременський протокол - II Зимова академія - Освіта з Свропою). Сама назва дозволяє віднести текст до дипломатичного жанру офіційно-ділового дискурсу - протокол. У свою чергу, жанр оригіналу обумовлює функції тексту - інформативну і перформативну.

Організатором міжнародного освітнього заходу під назвою Друга Зимова академія у м. Бремен (ФРН) стала німецька громадська організація Гете-Інститут. Автором тексту протоколу німецькою мовою виступив колектив мультиплікаторів (викладачів та популяризаторів німецької мови) Гете-Інституту, що працюють у відділеннях організації країн Східного партнерства, зокрема, в Україні та Грузії. У повному тексті протоколу йдеться про результати співробітництва чотирьох країн-учасниць проекту, присвяченого створенню Міжнародного мережевого онлайн-університету. Особливість тексту полягає в його поліадресатності, відтак німецький оригінал протоколу передбачав офіційний переклад трьома мовами: українською, російською та грузинською.

3 огляду на офіційний характер i професійний експертний статус перекладача Гете-Інституту, ми були вимушені встановити, що аналізований переклад не позбавлений суттєвих помилок, пов'язаних саме з відтворенням одиниць IE лексичного рівня оригіналу. Тому в межах психолінгвістичного експерименту ми відмовились від залучення офіційного перекладу як еталона для порівняння 3 паралельними перекладами напівпрофесійних перекладачів. Будучи керівником експерименту, ми прийняли рішення розглядати офіційний переклад лише як один із варіантів виконання перекладацького замовлення 3 боку носія професійного експертного статусу.

Отже, спочатку проаналізуємо особливості відтворення лексем-носіїв IE в офіційному перекладі протоколу українською мовою. Символом (*) в українському тексті позначені помилкові 
перекладацькі рішення, обумовлені психолінгвістичним фактором IE на лексичному рівні оригіналу (табл. 2).

Таблиця 2. Порівняння оригіналу i офіційного перекладу за критерієм відтворення одиниць-носіїв IЕ лексичного рівня у ЦТ

\begin{tabular}{|c|c|}
\hline $\begin{array}{l}\text { shbotschafter/-innen } \\
\text { botschafter/-innen } \\
\text { en } \\
\text { ersität koordinieren die } \\
\text { en einzelnen Institutionen } \\
n \text { erste Schritte für einen } \\
\text { zwerkes und fungieren } \\
\text { likatoren. }\end{array}$ & $\begin{array}{l}\text { (1а) Освітні посланники* } \\
\text { Освітні } \\
\text { Мережевого університету координують } \\
\text { зусилля у окремих інституціях. Вони } \\
\text { здійснюють перші кроки для налагодження } \\
\text { мережі та діють на перший час як } \\
\text { мультиплікатори. }\end{array}$ \\
\hline $\begin{array}{l}\text { (2) Dabei ist der Auf- und Ausbau der } \\
\text { Netzwerkuniversität nur eine Funktion, } \\
\text { angfristig sind die Tätigkeiten aber breit } \\
\text { gefächert. }\end{array}$ & $\begin{array}{l}\text { (2а) При иьому } \boldsymbol{n} \\
\text { Мережевого універс } \\
\text { функція, поле діяльн } \\
\text { перспективу широке }\end{array}$ \\
\hline $\begin{array}{l}\text { (3) Im Rahmen } \\
\text { anvisiert, ein } \boldsymbol{Z} \boldsymbol{u} \\
\text { zum / zur } \\
\text { konzipieren. }\end{array}$ & $\begin{array}{l}\text { (3а) В рамках Мережевого уніве } \\
\text { передбачається концептуальна } \\
\text { профіля* підготовки /під } \\
\text { кваліфікації* до освітнього посла }\end{array}$ \\
\hline \begin{tabular}{ll} 
(4) Die mögliche & \multicolumn{2}{c}{ Instanz } \\
Bildungsbotschafters & \multicolumn{2}{c}{$/$} \\
Bildungsbotschafterin & \multicolumn{2}{c}{ an } \\
Bildungsinstitutionen wird von \\
Beteiligten begrüß $\beta$ und im R \\
des Voranschreitens der internati
\end{tabular} & $\begin{array}{l}\text { (4а) Можлива інстанція* освітнього } \\
\text { посланника* у навчальних закладах } \\
\text { вітається усіма учасниками та } \\
\text { підтримується в рамках просування * } \\
\text { Міжнародного мережевого університету. }\end{array}$ \\
\hline
\end{tabular}

Для зручності порівняльно-перекладацького аналізу таблиця 2 розбита на дві колонки і чотири рядки (1-1a), (2-2a), (3-3a), (4-4a). У лівій колонці розміщено фрагмент вихідного тексту протоколу (Bremer Protokoll, 2017), у правій колонці знаходиться офіційний переклад українською мовою (Бременський протокол, 2017). Кожний рядок відповідає смисловим відрізкам тексту, реалізованим як на рівні окремих речень (2-2a), (3-3a), (4-4a), так і на рівні надфразової єдності (1-1a).

Під час розгляду кожного зі смислових відрізків були встановлені лексеми оригіналу, помилково відтворені у перекладі. Рядок (1-1a) демонструє хибне відтворення абстрактного двохосновного іменника множини з так званим гендерним маркером /-innen: Bildungsbotschafter/-innen. В українському перекладі 
виконавець відтворює цю одиницю послівно, шляхом калькування предметно-логічного значення кожної з основ: освітні посланники*. Ми вважаємо наведене перекладацьке рішення помилковим 3 двох причин: 1) воно викривлює первинну пропозицію (смисл) оригіналу; 2) воно суперечить жанрово-стилістичним нормам цільового офіційно-ділового дискурсу.

У цьому випадку йдеться про явище IE лексичного рівня, пов'язане, по-перше, 3 непередбачуваністю німецької лексеми Bildungsbotschafter в офіційно-діловому типі дискурсу та жанрі «протокол», а по-друге, із можливістю багатоваріантної інтерпретації складного іменника. Можна стверджувати, що перекладач не «відчуває» контекстно-ситуативну інформацію як інваріант перекладу i помилково обирає знаковий спосіб трансляції одиниці через відтворення iï семантичних складників. Інакше кажучи, у свідомості перекладача відбулось пригнічення контекстуального значення лексеми ВТ через предметно-логічне значення, що ми i спостерігаємо в трансляті.

Враховуючи фактори комунікативної ситуації, до якої уміщено вихідний текст, а також вимоги цільового дискурсу, пропонуємо авторський варіант перекладу лексеми-носія IE: нім. Bildungsbotschafter - укр. координатори міжнародних освітніх програм/проектів (МОП). Наведений варіант відзначається смисловим способом перекладу і вибором перекладацького рішення для передачі дискурсивно-ситуативної інформації оригіналу, орієнтованої на адресата.

У другому рядку (2-2a) спостерігаємо неточне відтворення абстрактного віддієслівного іменника der Aufbau за допомогою знакового способу перекладу: укр. побудова. Крім того, у перекладі має місце тавтологія іменників побудова i розбудова, що $\epsilon$ стилістично неприпустимим явищем в офіційно-діловому документі. Наведене рішення також пояснюється неправильним вибором перекладача на користь відтворення семантичної інформації одиниці перекладу ВТ. Очевидно, що в німецькому тексті протоколу малась на увазі не побудова, а створення Міжнародного мережевого онлайн-університету, зрозуміле 3 контексту.

Перекладацькі рішення у третьому рядку (3-3a) також стосуються хибної передачі семантичної інформації орігіналу замість відтворення дискурсивно-ситуативної інформації як інваріанта 
перекладу. Лексеми Zusatzprofil/Weiterbildungsprofil відтворюються гібридним знаково-смисловим способом через калькування одного складника (профіль), додавання (підготовка) та переклад іншого семантичного складника (підвищення кваліфікаціï) двохосновних іменників: укр. профіль підготовки/підвищення кваліфікащії*.

У наведеному прикладі знову спостерігаємо неправильний вибір перекладацького рішення, зумовлений IE лексичних одиниць оригіналу. Якщо використати смисловий спосіб перекладу, що грунтується на розумінні контексту, факторів комунікативної ситуації, насамперед предмета повідомлення, та відповідності нормам цільового освітнього дискурсу, варіант відтворення цих одиниць виглядає так: укр. програма професійної перепідготовки/ додаткової кваліфікащії.

Розгляньмо останній рядок (4-4a). Тут мають місце два аналогічні випадки хибного відтворення абстрактного іменника die Instanz та складного віддієслівного іменника das Voranschreiten шляхом уживання знакового способу перекладу. Вирішальну роль у виборі перекладацького рішення знов мало пригнічення контекстуального значення лексем через предметно-логічне значення у свідомості перекладача, що призвело до часткового викривлення змісту відрізку (4). Авторський варіант відтворення наведених носіїв IE виглядає так: нім. Instanz - укр. посада; нім. im Rahmen des Voranschreitens - укр. у перспективі розвитку (смисловий спосіб перекладу).

Підсумовуючи розгляд відтворення носіїв IE в офіційному перекладі, слід зазначити, що із 16 одиниць IE лексичного рівня 6 одиниць були помилково відтворені за допомогою знакового способу перекладу. Суб'єктивний вибір хибного інваріанту перекладу (семантичної інформації) з боку перекладача призвів до появи помилок на трьох рівнях трансляту: (1) мовному (Aufbau побудова*, Instanz - інстанція*, Voranschreiten - просування*), (2) жанрово-стилістичному (Bildungsbotschafter - освітні посланники*), (3) фаховому (Zusatz/Weiterbildungsprofil - nрофіль підготовки/підвищення кваліфікації*).

Наведений факт свідчить про недостатній ступень розвиненості мовної, перекладацької та фахової компетенції суб'єкта перекладу відповідно. Крім того, припускаємо, що перекладач за об'єктивних обставин (наприклад, брак часу) був лише поверхнево ознайомлений 
з факторами комунікативної ситуації вихідного тексту, тобто даними про автора, предмет повідомлення i потенційними адресатами, що суттєво знизило якість перекладу.

Розгляньмо відтворення носіїв IE лексичного рівня $\mathrm{y}$ множинних перекладах учасників психолінгвістичного експерименту. Для цього скористаємось контрольним варіантом А. Символом (*) в контрольному варіанті перекладу А позначені помилкові рішення перекладача, обумовлені фактором IE лексичного рівня оригіналу (табл. 3).

Таблиця 3. Порівняння оригіналу i контрольного варіанту перекладу А за критерієм відтворення одиниць-носіїв IE лексичного рівня

\begin{tabular}{|c|c|}
\hline $\begin{array}{l}\text { Die Bildungsbotschafter/-innen } \\
\text { Koordinatoren/-innen } \\
\text { der Netzwerkuniversität koordinieren } \\
\text { dieBemühungen an den einzelnen Institutionen } \\
\text { vor Ort. Sie leisten erste Schritte für einen } \\
\text { Aufbau des Netzwerkes und fungieren zunächst } \\
\text { als Multiplikatoren. }\end{array}$ & $\begin{array}{l}\text { (1а) Посли з питань просвіти* } \\
\text { Посли з питань просвіти* } \\
\text { координатори цифрового* мережевого } \\
\text { університету координують роботу } \\
\text { окремих закладів* на місиях. Вони } \\
\text { роблять пермі кроки на шляху } \\
\text { до побудови мережі і передусім } \\
\text { виступають у ролі мультиплікаторів. }\end{array}$ \\
\hline $\begin{array}{l}\text { (2) Dabei ist der Auf- und Ausbau der } \\
\text { Netzwerkuniversität nur eine Funktion, } \\
\text { langfristig sind die Tätigkeiten aber breit } \\
\text { gefächert. }\end{array}$ & $\begin{array}{l}\text { (2а) При ивому побудова* i розбудова } \\
\text { Мережевого університету - ие лише } \\
\text { одна з функиій, у довготривалій } \\
\text { перспективі передбачений широкий } \\
\text { спектр напрямів діяльності. }\end{array}$ \\
\hline $\begin{array}{l}\text { (3) Im Rahmen der Netzwerkuniversität ist } \\
\text { anvisiert, ein Zusatz- / Weiterbildungsprofil } \\
\text { zum / zur Bildungsbotschafter/-in zu } \\
\text { konzipieren. }\end{array}$ & $\begin{array}{l}\text { (3а) У рамках цифрового* мережевого } \\
\text { університету планується розробити } \\
\text { додатковий профіль* навчання* / } \\
\text { підвищення кваліфікації* на посла } \\
\text { питань просвіти*. }\end{array}$ \\
\hline $\begin{array}{lcr}\text { (4) Die mögliche } & \text { Instanz } & \text { eines } \\
\text { Bildungsbotschafters } & / & \text { der } \\
\text { Bildungsbotschafterin } & \text { an } & \text { den } \\
\text { Bildungsinstitutionen wird von allen } & \text { Beteiligten } \\
\text { begrüßt und im Rahmen des Voranschreitens der }\end{array}$ & $\begin{array}{lll}\text { (4а) Ідея створення } & \text { iн } \\
\text { для послів } \mathbf{3} \text { питань } & \boldsymbol{n}_{\mathbf{r}} \\
\text { була підтримана усіма } & \text { уч } \\
i \quad \text { отримала сприяння } & \text { в } \\
\text { розвитку Міжнародного } & \text { ме } \\
\text { університету. }\end{array}$ \\
\hline
\end{tabular}

3 метою уніфікації процесу порівняльно-перекладацького аналізу таблиця 3 має однакову структуру колонок i рядків 3 таблицею 2 (див. вище). У контрольному перекладі А спостерігаємо 4 випадки помилкового відтворення одних і таких самих одиниць оригіналу, як і в офіційному перекладі, а саме: Bildungsbotschafter, Aufbau, Zusatz/Weiterbildungsprofil, Instanz. Наведений факт 
вказує на універсальний характер негативного впливу полісемії та непередбачуваності на результат перекладу, незалежно від експертного статусу його виконавця (професіонал/напівпрофесіонал).

Причому у двох випадках одиниці відтворення лексем-носіїв IE y перекладі А повністю ідентичні 3 офіційним перекладом: (1) Aufbau - побудова*; (2) Instanz - інстанція*. У двох інших випадках розходження у відтворенні носіїв IE в перекладі А 3 офіційним перекладом мають непринциповий характер: (3) Bildungsbotschafter - посли 3 питань просвіми*; (4) Zusatz/ Weiterbildungsprofil - профіль навчання/підвищення кваліфікації*. Наведені приклади свідчать про схожі психолінгвістичні механізми відтворення одиниць високого рівня IE у різних виконавців. Можна припустити, що знаковий спосіб перекладу у вигляді транслітерації (інстанція, профіль) та калькування (посли з питань просвіти, освітні посланники) перекладачі використовують з метою економії інтелектуальних зусиль, оскільки текст оригіналу загалом має високу частоту носіїв IE. Відомо, що смисловий спосіб перекладу вимагає вищого рівня перекладацької компетенції, яка реалізується у більш високому ступені кооперації між елементами нейронних мереж мозку, зокрема одночасній задіяності когнітивних процесів пригадування, абстрагування, інтерпретації та переформулювання/ парафразування інформації.

Якщо порівняти загальну кількість похибок у відтворенні носіїв IE лексичного рівня в контрольному та офіційному варіантах перекладу, можна встановити загальне відношення 7:6, тобто 7 помилок у трансляті напівпрофесійного перекладача відповідають 6 помилкам професійного суб'єкта перекладу. Наведені показники свідчать про достатній рівень сформованості мовної та перекладацької компетенцій інформанта, що дозволило йому правильно відтворити у перекладі 9 із 16 одиниць-носіїв IE (56,0\% коректних перекладацьких рішень).

Під час аналізу множинних перекладів інших учасників експерименту з'ясувалось, що більша частина інформантів (53 особи із 85, тобто 62,0\% від загальної кількості) скористались екстралінгвістичною інформацією, наданою у завданні (див. 1.1., табл. 1, також див. табл. 4). Цей фактор значно підвищив якість перекладу i знизив кількість помилкових рішень у передачі носіїв інформаційної ентропії. Розгляньмо кількісні дані у таблиці 4. 
Таблиця 4. Співвідношення між типом одиниць-носіїв IE лексичного рівня, способом їхнього відтворення та кількістю перекладів інформантів

\begin{tabular}{|c|c|c|c|c|}
\hline \multirow{7}{*}{$\begin{array}{l}\text { Тип одиниці } \\
\text { ІЕ лексичного рівня }\end{array}$} & \multicolumn{4}{|c|}{$\begin{array}{c}\text { загальна кількість інформантів } \\
\text { (проаналізованих множинних перекладів) }\end{array}$} \\
\hline & \multicolumn{4}{|c|}{85} \\
\hline & \multicolumn{4}{|c|}{$\begin{array}{c}\text { кількість інформантів, які врахували } \\
\text { екстралінгвістичну інформацію у перекладі }\end{array}$} \\
\hline & \multicolumn{2}{|c|}{ ні } & \multicolumn{2}{|c|}{ так } \\
\hline & \multicolumn{2}{|c|}{32} & \multicolumn{2}{|c|}{53} \\
\hline & \multicolumn{2}{|c|}{$\begin{array}{c}\text { кількість випадків уживання } \\
\text { знакового способу } \\
\text { ерекладу одиниці IE }\end{array}$} & \multicolumn{2}{|c|}{$\begin{array}{c}\text { кількість випадків уживання } \\
\text { смислового способу } \\
\text { перекладу одиниці IE }\end{array}$} \\
\hline & $\begin{array}{c}\text { адекватний } \\
\text { переклад }\end{array}$ & $\begin{array}{c}\text { хибний } \\
\text { переклад }\end{array}$ & $\begin{array}{c}\text { адекватний } \\
\text { переклад }\end{array}$ & $\begin{array}{c}\text { хибний } \\
\text { переклад }\end{array}$ \\
\hline $\begin{array}{l}\text { заголовок тексту } \\
\text { Bildungsbotschafter/- } \\
\text { innen }\end{array}$ & - & 32 & 4 & 49 \\
\hline $\begin{array}{l}\text { віддієслівний іменник } \\
\text { der Aufbau }\end{array}$ & 68 & 17 & - & - \\
\hline $\begin{array}{l}\text { абстрактний іменник } \\
\text { die Funktion }\end{array}$ & - & 36 & 49 & - \\
\hline $\begin{array}{l}\text { термін фахового } \\
\text { дискурсу освіти } \\
\text { der Multiplikator }\end{array}$ & - & 53 & 25 & 7 \\
\hline $\begin{array}{l}\text { термін фахового } \\
\text { дискурсу освіти } \\
\text { das Zusatz/ } \\
\text { Weiterbildungsprofil }\end{array}$ & - & 84 & 1 & - \\
\hline $\begin{array}{l}\text { Абстрактний іменник } \\
\text { die Instanz. }\end{array}$ & - & 64 & - & 21 \\
\hline
\end{tabular}

Як бачимо, у 53 проаналізованих варіантах заголовок тексту відтворено за допомогою смислового способу перекладу (координатори з питань освіти, координатори з питань просвіти*,

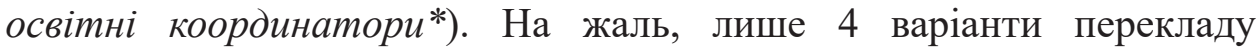
заголовка виявились адекватними. У 68 варіантах лексема der Aufbau коректно відтворюється в контексті фрагмента як заснування або створення. 49 варіантів демонструють відмову від транслітерації функиія під час відтворення німецької лексеми Funktion - укр. завдання. У 32 варіантах знаходимо смисловий або описовий спосіб перекладу лексеми Multiplikator: просвітитель*, популяризатор, ті, хто займаються просвітницькою діяльністю, інформатор у 
питаннях освіти*. Слід зазначити, що у 25 випадках відтворення лексеми було адекватним.

Втім, деякі одиниці-носії IE виявились занадто складними для розуміння й відтворення з боку учасників експерименту. Так, лише в одному з 85 варіантів перекладу знайшовся (частково) правильний ситуативний відповідник одиниць Zusatz/Weiterbildungsprofil: післядипломна освітня програма підготовки. Жоден 3 інформантів не зміг адекватно відтворити лексему Instanz, намагаючись застосувати або транслітерацію, або описовий спосіб перекладу: інстаниія*, присутність освітніх координаторів у навчальних установах*, структура освітніх координаторів* (див. табл. 4).

Ми вважаємо, що наведений результат спричинено суб'єктивною недостатністю фахової компетенції перекладачів у галузі вищої освіти (відтворення терміна Zusatz/Weiterbildungsprofil) та нерозумінням одного 3 факторів комунікативної ситуації ВТ (відтворення іменника Instanz).

\section{Висновки}

Підсумовуючи результати аналізу відтворення лексичних одиниць-носіїв інформаційної ентропії оригіналу в офіційному перекладі та множинних перекладах інформантів, ми дійшли таких висновків:

1. Поняття інформаційної ентропії як психолінгвістичного фактору зниження якості перекладу становить проміжну ланку між психолінгвістикою i перекладознавством. Інформаційна ентропія у психолінгвістичному розумінні становить суб'єктивну міру невизначеності інформації про об'єкт перекладу (інформаційний дефіцит у свідомості перекладача), який зумовлює хибні перекладацькі рішення на рівні відтворення структурно-семантичної, комунікативно-прагматичної, дискурсивно-фахової та фонової інформації оригіналу в перекладі.

2. Явище інформаційної ентропії як суб'єктивного дефіциту інформації будь-якого типу може виникати на рівнях лексеми, словосполучення, колокації, речення, надфразової єдності вихідного тексту, що призводить до нерозуміння цілого тексту оригіналу або його значущої частини. 
3. До об’єктивних ознак інформаційної ентропії одиниць на лексичному рівні вихідного тексту належать полісемія, синонімія та непередбачуваність уживання конкретних одиниць в тексті оригіналу. Психолінгвістичний фактор неправильного відтворення одиниць-носіїв IE у перекладі обумовлено когнітивною здатністю перекладача одночасно утримувати у свідомості обидва значення лексичної одиниці: предметно-логічне та контекстуальне. Якщо у свідомості виконавця перекладу переважає мовна компетенція, відбувається вибір на користь предметно-логічного значення одиниці та ii відтворення шляхом знакового способу перекладу. У випадку превалювання перекладацької компетенції виконавець обирає контекстуальне значення лексеми і відтворює іiі за допомогою смислового способу перекладу.

4. Психолінгвістичний експеримент за участю 85 осіб напівпрофесійних перекладачів - підтвердив нашу гіпотезу про універсальний характер впливу IE на результат перекладу у бік зниження якості останнього. Було встановлено інвентар лексичних одиниць-носіїв інформаційної ентропії у вихідному тексті.

5. Шляхи подолання інформаційної ентропії оригіналу суб'єктивного рівня передбачають підвищення перекладацької та галузевої компетенцій перекладачів, тобто накопичення фахових і спеціальних знань про перекладацький інструментарій та галузі людської життєдіяльності, до яких належать об’єкти перекладу. Такі компетенції включають уміння перекладача користуватись теоретико-методологічним інструментарієм перекладознавства, алгоритмами доперекладацького аналізу тексту, спеціалізованими артефактами, а також паралельними текстами, що відносяться до сфери використання й жанру оригіналу.

6. Суб'єктивна інформаційна ентропія вихідного тексту на локальному рівні, зокрема ентропія лексичних одиниць, призводить до викривлення смислу перекладного тексту на глобальному рівні, тому іiі слід вважати психолінгвістичною проблемою перекладу спеціальних текстів.

Перспективою подальших досліджень у напрямку психолінгвістики перекладу може слугувати вивчення суб'єктивної інформаційної ентропії на синтаксичному й композиційнотекстовому рівнях, а також встановлення кореляцій між рівнем IE та типом перекладацьких помилок. 


\section{Література}

Андрієнко, Т.П. (2014). Інформаційні характеристики тексту як фактор реалізації стратегії перекладу. Мовні і концептуальні картини світу, 48, 25-36.

Андрієнко, Т.П. (2016). Стратегії $і$ тактики перекладу: когнітивно-дискурсивний аспект (на матеріалі художнього перекладу з англійської мови на украӥнську та російську). Київ: Видавничий дім Дмитра Бураго.

Бременський протокол. (2017). II Зимова академія - Освіта 3 Свропою. Мережевий онлайн-університет (Бремен, 4-6 грудня 2017 року). Handout.

Дорофеєва, М.С. (2017). Синергетика перекладу спеціальних текстів (німецькоукраїнський напрям). Київ: Видавничий дім Дмитра Бураго.

Залевская, А.А. (2000). Введение в психолингвистику. Москва: РГГУ.

Селіванова, О.О. (2008). Сучасна лінгвістика: напрями та проблеми. Полтава: Довкілля.

Швейцер, А.Д. (1988). Теория перевода: Статус, проблемы, аспекты. Москва: Наука.

Baayen, R.H. (2005). Data mining at the intersection of psychology and linguistics. In A. Cutler (Ed.), Twenty-First Century Psycholinguistics: Four Cornerstones (pp. 69-84). London: Lawrence Erlbaum.

Bogush, A., Korolova, T., \& Popova, O. (2019). Development of the future translator's professional competency in bilateral interpreting: modern methods. Advanced education, 11, 10-21. https://doi.org/10.20535/2410-8286.156577

Bremer Protokoll. (2017). II Winterakademie - Bildung mit Europa. Digitale Netzwerkuni (Bremen, Dezember 4-6, 2017). Handout.

Haken, H. et al. (2016). Beiträge zur Geschichte der Synergetik. Allgemeine Prinzipien der Selbstorganisation in Natur und Gesellschaft. Wiesbaden: Springer. https:// doi.org/10.1007/978-3-658-12952-1

Hatzidaki, A., \& Pothos, E.M. (2008). Bilingual language representation and cognitive processes in translation. Applied Psycholinguistics, 29(1), 125-150. https://doi. org/10.1017/S0142716408080065

House, J. (2013). Towards a new linguistic-cognitive orientation in translation studies. Target, 25(1), 46-60. https://doi.org/10.1075/target.25.1.05hou

Keller, F. (2004). The entropy rate principle as a predictor of processing effort: An evaluation against eye-tracking data. Proceedings of the Conference on Empirical Methods in Natural Language Processing (pp. 317-324). Barcelona.

Lewis, M.L., \& Frank, M.C. (2016). The length of words reflects their conceptual complexity. Cognition, 153, 182-195. https://doi.org/10.1016/j. cognition.2016.04.003

Prior, A., Wintner, S., MacWhinney, B., \& Lavie, A. (2011). Translation ambiguity in and out of context. Applied Psycholinguistics, 32(1), 93-111. https://doi. org/10.1017/S0142716410000305

Prunč, E. (2012). Entwicklungslinien der Translationswissenschaft. Von den Asymmetrien der Sprachen zu den Asymmetrien der Macht. Berlin: Frank \& Timme.

Texteira, C.S.C., \& O'Brien, S. (2017). Inverstigating the cognitive ergonomic aspects of translation tools in a workplace setting. Translation spaces, 6(1), 79-103. https://doi.org/10.1075/ts.6.1.05tei

Chernovaty, L., \& Kovalchuk, N. (2019). Teaching non-fiction translation: The System of Exercises and Tasks. Advanced Education, 12, 5-11. https://doi. org/10.20535/2410-8286.155535 


\section{References}

Andriienko, T.P. (2014). Informatsiini kharakterystyky tekstu yak faktor realizatsii stratehii perekladu [Informational characteristics of the text as a factor in the implementation of the translation strategy]. Movni i kontseptualni kartyny svitu Linguistic and conceptual pictures of the world, 48, 25-36 [in Ukrainian].

Andriienko, T.P. (2016). Stratehii $i$ taktyky perekladu: kohnityvno-dyskursyvnyi aspekt (na materiali khudozhnoho perekladu z anhliiskoi movy na ukrainsku ta rosiisku) [Strategies and tactics of translation: cognitive-discursive aspect (based on the literary translation from English into Ukrainian and Russian)]. Kyiv: Vydavnychyi dim Dmytra Buraho [in Ukrainian].

Bremenskyi protokol [Bremen Protocol]. (2017). II Zymova akademiia - Osvita z Yevropoiu. Merezhevyi onlain-universytet [Second Winter Academy - Education with Europe. Online Network University] (Bremen, December 4-6, 2017]. Handout.

Dorofeieva, M.S. (2017). Synerhetyka perekladu spetsialnykh tekstiv (nimetskoukrainskyi napriam) [Synergetics of Specialized Texts Translation (GermanUkrainian direction)]. Kyiv: Vydavnychyi dim Dmytra Buraho [in Ukrainian].

Zalevskaja, A.A. (2000). Vvedenie v psiholingvistiku [Introduction to Psycholinguistics]. Moscow: RGGU [in Russian].

Selivanova, O.O. (2008). Suchasna linhvistyka: napriamy ta problem [Modern Linguistics: Trends and Challenges]. Poltava: Dovkillia [in Ukrainian].

Shvejcer, A.D. (1988). Teorija perevoda: Status, problemy, aspekty [Translation theory: status, problems, aspects]. Moscow: Nauka [in Russian].

Baayen, R.H. (2005). Data mining at the intersection of psychology and linguistics. In A. Cutler (Ed.), Twenty-First Century Psycholinguistics: Four Cornerstones (pp. 69-84). London: Lawrence Erlbaum.

Bogush, A., Korolova, T., \& Popova, O. (2019). Development of the future translator's professional competency in bilateral interpreting: modern methods. Advanced education, 11, 10-21. https://doi.org/10.20535/2410-8286.156577

Bremer Protokoll. (2017). II Winterakademie - Bildung mit Europa. Digitale Netzwerkuni (Bremen, Dezember 4-6, 2017). Handout.

Haken, H. et al. (2016). Beiträge zur Geschichte der Synergetik. Allgemeine Prinzipien der Selbstorganisation in Natur und Gesellschaft. Wiesbaden: Springer. https:// doi.org/10.1007/978-3-658-12952-1

Hatzidaki, A., \& Pothos, E.M. (2008). Bilingual language representation and cognitive processes in translation. Applied Psycholinguistics, 29(1), 125-150. https://doi. org/10.1017/S0142716408080065

House, J. (2013). Towards a new linguistic-cognitive orientation in translation studies. Target, 25(1), 46-60. https://doi.org/10.1075/target.25.1.05hou

Keller, F. (2004). The entropy rate principle as a predictor of processing effort: An evaluation against eye-tracking data. Proceedings of the Conference on Empirical Methods in Natural Language Processing (pp. 317-324). Barcelona.

Lewis, M.L., \& Frank, M.C. (2016). The length of words reflects their conceptual complexity. Cognition, 153, 182-195. https://doi.org/10.1016/j. cognition.2016.04.003

Prior, A., Wintner, S., MacWhinney, B., \& Lavie, A. (2011). Translation ambiguity in and out of context. Applied Psycholinguistics, 32(1), 93-111. https://doi. org/10.1017/S0142716410000305 
Prunč, E. (2012). Entwicklungslinien der Translationswissenschaft. Von den Asymmetrien der Sprachen zu den Asymmetrien der Macht. Berlin: Frank \& Timme.

Texteira, C.S.C., \& O'Brien, S. (2017). Inverstigating the cognitive ergonomic aspects of translation tools in a workplace setting. Translation spaces, 6(1), 79-103. https://doi.org/10.1075/ts.6.1.05tei

Chernovaty, L., \& Kovalchuk, N. (2019). Teaching non-fiction translation: The System of Exercises and Tasks. Advanced Education, 12, 5-11. https://doi. org/10.20535/2410-8286.155535

\section{АНОТАЦІЯ}

У статті розглянуто категорію інформаційної ентропії вихідного тексту з позицій психолінгвістики перекладу. Інформаційна ентропія одиниць оригіналу різних рівнів, згідно із гіпотезою дослідження, належить до суб'єктивних факторів зниження якості перекладу. Мовні одиниці-носії інформаційної ентропії вихідного тексту, в першу чергу на лексичному рівні, спричинюють інформаційні дефріцити у свідомості перекладача.

Мета дослідження полягає у висвітленні категорії інформаційної ентропії у річищі психолінгвістики та когнітивної теорії перекладу, виявленні причин виникнення інформаційної ентропії, встановленні мовних та жанровостилістичних ознак ентропії лексичних одиниць оригіналу, окресленні шляхів мінімізації ентропії у перекладі спеціальних текстів.

Процедура дослідження для вирішення поставлених завдань включає психолінгвістичний експеримент за участю 85 інформантів із напівпрофресійним перекладацьким статусом. Учасники експерименту виконали німецькоукраїнський переклад спеціального тексту, де кількість лексем-носіїв інформаційної ентропії у відсотковому відношенні до загальної кількості слів становила $17,9 \%$.

Результати порівняння множинних перекладів інформантів, офрічійного перекладу та авторського перекладу свідчать про схожі психолінгвістичні механізми розуміння лексичних одиниць-носіїв інфрормаційної ентропії, що призводять до хибних перекладацьких рішень у цільових текстах різних виконавців. Такі механізми включають неправильний вибір способу перекладу і неврахування екстралінгвістичної інформації щодо тексту оригіналу.

Висновки психолінгвістичного експерименту підтверджують універсальний характер впливу інформаційної ентропії на результат перекладу у бік зниження якості останнього. Об'єктивні причини виникнення інформачійної ентропії на лексичному рівні оригіналу включають полісемію $і$ непередбачуваність лексичних одиниць в конкретному типі тексту. Психолінгвістична причина хибного перекладацького рішення полягає в автоматичному пригніченні контекстуального значення вихідної лексеми через ії предметно-логічне значення у свідомості перекладача, що реалізується у неправильному виборі способу перекладу.

Ключові слова: інформаційна ентропія, лексичний рівень, оригінал, переклад, психолінгвістичний експеримент, знаковий спосіб перекладу, смисловий спосіб перекладу, компетенція перекладача. 
Information Entropy in Translation: Psycholinguistic Aspects

Дорофеева Маргарита, Андрущенко Татьяна. Информационная энтропия в переводе: психолингвистические аспекты

\section{АННОТАЦИЯ}

В статье рассмотрена категория информационной энтропии исходного текста с точки зрения психолингвистики перевода. Информационная энтропия единиц оригинала разных уровней, согласно гипотезе исследования, относится к субъективным факторам снижения качества перевода. Языковые единицы-носители информационной энтропии исходного текста, прежде всего на лексическом уровне, вызывают информационные дефициты в сознании субъекта перевода.

Цель разыскания состоит в рассмотрении категории информационной энтропии с позиций психолингвистики и когнитивной теории перевода, выявлении причин возникновения информационной энтропии, установлении языковых и жанрово-стилистических признаков энтропии лексических единиц оригинала, определении путей минимизации энтропии в переводе специальных текстов.

Процедура исследования для решения поставленных задач включает психолингвистический эксперимент с участием 85 информантов с полупрофессиональным переводческим статусом. Участники эксперимента выполнили немецко-украинский перевод специального текста, в котором количество лексем-носителей информационной энтропии в процентном отношении к общему количеству слов составило 17,9\%.

Результаты сравнительного анализа множественных переводов информантов, официального перевода и авторского перевода свидетельствуют о схожих психолингвистических механизмах понимания лексических единиц-носителей инфрормачионной энтропии, приводящих к ошибочным переводческим решениям в целевых текстах разных переводчиков. Такие механизмы включают неверный выбор способа перевода и отсутствие внимания к экстралингвистической информации текста оригинала.

Выводы психолингвистического эксперимента подтверждают универсальный характер влияния информационной энтропии на результат перевода $в$ сторону снижения его качества. Объективные причины возникновения информационной энтропии на лексическом уровне оригинала включают полисемию и непредсказуемость лексических единии в конкретном типе текста. Психолингвистическая причина неверного выбора переводческого решения состоит в автоматическом угнетении контекстуального значения исходной лексемы ее предметно-логчческим значением в сознании переводчика, которое реализуется в ошибочном выборе способа перевода.

Ключевые слова: информационная энтропия, лексический уровень, оригинал, перевод, психолингвистический эксперимент, знаковый способ перевода, смысловой способ перевода, компетенция переводчика. 